Abstracta Iranica Abstracta Iranica

Revue bibliographique pour le domaine irano-aryen

Volume 32-33 | 2013

Comptes rendus des publications de 2009-2010

\title{
J. Elayi, A. G. Elayi. The Coinage of the Phonician City of Tyre in the Persian Period ( $5^{\text {th }}-4^{\text {th }}$ cent. BCE)
}

\section{Astrid Nunn}

\section{OpenEdition}

1 Journals

Édition électronique

URL : http://journals.openedition.org/abstractairanica/40248

DOI : 10.4000/abstractairanica.40248

ISSN : 1961-960X

\section{Éditeur :}

CNRS (UMR 7528 Mondes iraniens et indiens), Éditions de l'IFRI

\section{Édition imprimée}

Date de publication : 1 décembre 2013

ISSN : 0240-8910

\section{Référence électronique}

Astrid Nunn, « J. Elayi, A. G. Elayi. The Coinage of the Phonician City of Tyre in the Persian Period $\left(5^{\text {th }}-4^{\text {th }}\right.$ cent. BCE) », Abstracta Iranica [En ligne], Volume 32-33 | 2013, document 58, mis en ligne le 01 juillet 2016, consulté le 27 septembre 2020. URL : http://journals.openedition.org/abstractairanica/40248 ; DOI : https://doi.org/10.4000/abstractairanica.40248

Ce document a été généré automatiquement le 27 septembre 2020.

Tous droits réservés 


\title{
J. Elayi, A. G. Elayi. The Coinage of the Phonician City of Tyre in the Persian Period ( $5^{\text {th }}-4^{\text {th }}$ cent. BCE)
}

\author{
Astrid Nunn
}

\section{RÉFÉRENCE}

J. Elayi, A. G. Elayi. The Coinage of the Phonician City of Tyre in the Persian Period $\left(5^{\text {th }}-4^{\text {th }}\right.$ cent. $B C E)$. Louvain, Peeters, 2009, 517 p. et 51 planches. (OLA 188 et StPh 20)

1 Cet ouvrage représente le second de quatre volumes sur le monnayage des cités phéniciennes sous domination perse (pour Sidon voir Abs. Ir. 28, 2005, n 82). Il débute avec le catalogue chronologique de 1814 pièces en argent et en bronze (p. 28-200). L'analyse qui suit comprend la chronologie, la production, les ateliers, les émissions, les techniques mais aussi les inscriptions et l'iconographie. Le hibou et le dauphin représentent les motifs les plus fréquents, suivis de l'hippocampe, d'une divinité qui pourrait être Melqart, d'un coquillage, d'une tête de lion, d'une tête de bélier et d'une rosette. Au-delà de la numismatique propre, l'étude des monnaies mènent à des conclusions sur l'histoire de la cité - ainsi fut introduit un système de datation annuelle vers 388 - et sur la politique des Achéménides à l'ouest, tout particulièrement sur celle de la $1^{\text {ère }}$ moitié du IV ${ }^{\mathrm{e}}$ s., époque à laquelle la ville concurrente de Sidon était en déclin (p. 323-389). 


\section{AUTEURS}

\section{ASTRID NUNN}

Université de Munich 